\title{
Askeri Ergonomi Çalışmaları için Literatür Taraması
}

\section{Literature Review for Military Ergonomics Studies}

\author{
Kemal Gürol Kurtay1 ${ }^{\text {iD, }}$, Yunus Gökmen ${ }^{1}$ iD, Hakan Ayhan Dağıstanlı1 ${ }^{\text {iD }}$ Recep Semih Topaklı1 ${ }^{\text {iD }}$ \\ ${ }^{1}$ Milli Savunma Üniversitesi Kara Harp Okulu Dekanlı̆̆ Endüstri ve Sistem Mühendisliği Bölüm Başkanlı̆̆l, O6530 Ankara, TÜRKIYE
}

Başvuru/Received: 01/10/2021ＫKabul/Accepted: 30/12/2021Ｃ̧evrimiçi Basım/Published Online: 31/12/2021 Son Versiyon/Final Version: 31/12/2021

\begin{abstract}
Öz
Ergonomi insanların anatomilerini, antropometrik ölçülerini, fiziksel kapasitelerini ve toleranslarını değerlendirip iş ortamında bulunan faktörleri inceleyerek insan, makine, ortam ilişkisini araştıran disiplinlerarası bilim dalıdır. Ergonomi, sanayi devriminin sonucu olarak 1950'li yıllarda önem kazanmaya başlamış ve meydana gelen savaşlar sonucunda askeri alana yönelmiştir. Zamanla gelişen ve değişen koşullarla birlikte önemi gittikçe artmış, askeri sistemlerin tasarlanmasında antropometrik ölçülerle fizyolojik, psikolojik ve çevresel verilerin oluşturduğu birçok faktör incelenerek askeri uygulamalarda kullanılmaya başlanmıştır. Askeri sistemlerle ilgili tasarımlarda titreşim, aydınlatma, sıcaklık, gürültü, zehirli gazlar gibi çevresel etkenleri azaltıcı çözümler önemli rol oynamaktadır. Çok sayıda personelin aynı yerde yaşayabilmesini zorunlu kılan savaş gemisi, helikopter, uçak ve denizaltı gibi araçlardan bir askerin kullandığı silah kabzası gibi küçük parçalara kadar tüm askeri teçhizat ergonomi açısından inceleme sahası olmakta ve özel çözümler geliştirilmesini zorunlu kılmaktadır. Personelin verimli çalışabilmesi için ihtiyaç duyulan alanın antropometrik ölçülere göre tasarlanması gerekmekte ve yapılan bu ergonomik geliştirmeler ile orduların ve personelin savaş etkinliği arttırılarak operasyonlardan elde edilecek başarı oranının yükseltilmesi hedeflenmektedir. Tasarımcıların bu hedeflere ulaşabilmesi için araştırmacılar tarafından literatürde birçok çalışmanın yapıldığı görülmektedir. Bu çalışmada askeri ergonomi çalışmaları araştırılarak literatür incelemesi yapılmıştır. Amaç; günümüze kadar yapılan askeri alanlardaki ergonomi çalışmalarını inceleyerek problem sahalarını belirleyip bu alanda yeni çalışmalar yapacak araştırmacılar için literatürü özet halinde sınıflandırarak sunmak ve ileride yapılacak akademik çalışmalarda araştırmacılara yön göstermektir.
\end{abstract}

\section{Anahtar Kelimeler}

"Ergonomi, Askeri Ergonomi, Antropometri"

\begin{abstract}
Ergonomics is an interdisciplinary science that investigates the relationship between human, machine and environment by evaluating the anatomy, anthropometric dimensions, physical capacities and tolerances of people and examining the factors in the work environment. Ergonomics began to gain importance in the 1950s as a result of the industrial revolution and turned to the military field as a result of the wars. The importance of ergonomics has gradually increased with the developing and changing conditions over time. In the design of military systems, many factors created by anthropometric measurements and physiological, psychological and environmental data have been examined and started to be used in military applications. Solutions that reduce environmental factors such as vibration, lighting, temperature, noise and toxic gases play an important role in military systems designs. All military equipment, from vehicles such as warships, helicopters, airplanes and submarines, which make it mandatory for a large number of personnel to live in the same place, to small parts such as a gun handle used by a soldier, is a field of examination in terms of ergonomics and requires the development of special solutions. In order to work efficiently for the personnel, the required area should be designed according to anthropometric measurements, and with these ergonomic developments, it is aimed to increase the success rate of the operations by increasing the combat effectiveness of the armies and personnel. In order to achieve these goals for designers, it is seen that many studies have been carried out by researchers in the literature. In this study, military ergonomics studies were investigated and a literature review was made. The aim is to present the literature in summary form for researchers who will examine the ergonomics studies in the military fields, identify the problem areas and make new studies in this field, and guide the researchers in future academic studies.
\end{abstract}

Key Words

"Ergonomics, Military Ergonomics, Anthropometry" 


\section{Giris}

İnsan, iş ve günlük yaşamdaki durumlara odaklanan ergonomi, iş ortamında bireylerin çalışma koşullarını inceleyerek etkilerini araştıran bilim dalıdır. İnsan faktörünün içinde bulunduğu tüm ortamları, makineleri, araçları ve bunların etkilerini araştırarak insan bedenine olan uyumu değerlendirmektedir. Ergonominin birincil amacı insan, makine ve ortam uyumunu sağlayarak meslek hastalıklarını, iş kazalarını önlemek, çalışanların güvenliğini ve performansını artırmaktadır. Ergonomi alanında insan faktörünün önemli bir kriter olması sebebiyle insanların beden ölçülerinin incelenmesi büyük önem taşımaktadır. Bu nedenle ergonomi ve antropometri birbirleriyle sıkı ilişki içerisinde olan iki farklı disiplindir.

Modern ergonomi bilimi 12 Temmuz 1949 yılında, İngiliz donanmasında yapılan insan ile iş arasındaki problemlerin değerlendirildiği bir toplantıda yer almış ve 16 Şubat 1950 tarihinde ergonomi terimi resmen kullanılmaya başlanmıştır. 1950'li yıllardan sonraki süreçlerde sanayi devrimi ve ekonomik problemlere bağlı olarak endüstriyel alanda uygulama çalışmaları yapılmıştır. Bu çalışmalarla çalışanların sağlı̆̆ını, güvenliğini, motivasyonunu ve verimliliğini arttırmak için çalışma ortamının tasarımında Ergonomi ve Antropometri biliminden yararlanılmıştır. 1950'li yıllarda Amerika Birleşik Devletleri'nde askeri problemlere çözüm bulunmasına yönelik çalışmalar yapılmış ve askeri alanda ergonomi bilimi bu çalışmalar ile önem kazanmaya başlamıştır. Sanayi ergonomisi 1960'lı yıllarda, tüketici ergonomisi 1970'li yıllarda öne çımıştır. Bu gelişmeler neticesinde değişen ve gelişen teknoloji ile birlikte makinelerin kullanım alanlarının artması, personelin makine ve dış ortam ile olan etkileşiminin fazlalığı ergonomi biliminin önemini arttırmıştır (North, 1997).

$\mathrm{Bu}$ çalışmada öncelikle ergonomi kavramının terimsel anlamda ortaya çıkışı ve bilim dünyasına girişi genel olarak ele alınmıştır. Ergonomi teriminin önemi ve bu alanda yapılan bilimsel çalışmaların getirdiği faydalara kısaca değinilmiştir. Daha sonra bu faydalara da bakılarak ergonomi kavramının tarihsel süreçte temelleri olduğu tahmin edilen milattan önceki çalş̧malardan bahsedilmiş ve 15. yüzyıldan 19. yüzyılın başına kadar ergonomik çalışmalara örnekler verilmiştir. 1906 yılındaki iş sağlığı konulu ilk uluslararası konferanstan, ergonomi biliminin dünyada ve ülkemizde üniversitelere ders niteliğinde kabul edilmesine kadar geçen süreç ise tarihçe başlığı altında özetlenmiştir. Bu aşamadan sonra çalışmamızın ana gövdesini oluşturan askeri alanda ergonominin rolü ve askeri silah, teçhizat ve malzemelerdeki ihtiyaç duyulan ergonomik gereksinimler çeşitli örnekler yardımıyla anlatılmıştır. Literatür taraması kısmında ise "Science Direct" ve "Google Akademik" veri tabanlarındaki hava, deniz ve kara kuvvetlerinde geçmişten günümüze yapılan ergonomik çalışmalar kronolojik olarak ele alınmıştır. Sonuç bölümünde askeri alanda yapılan ergonomi çalışmaları hakkında genel bir değerlendirme yapılmış ve gelecekte yapılabilecek çalışmalar hakkında çıkarımlarda bulunulmuştur.

\section{Ergonomi Hakkında Genel Bilgi}

\subsection{Ergonomi Kavramı ve Terimi}

Çalışanlar üzerinde incelemeler yaparak çalışma koşulların değerlendirilmesi İtalyan bilim adamı Bernardino Ramazzinni’nin yaptı̆̆ı çalışmalara dayanmaktadır. Aynı zamanda iş yeri hekimi olan Ramazzinni, 1700 yılında yazmış olduğu De Morbis Artificum (Çalışanların Hastalıkları) eserinde endüstride karşılaşı̆ı̆ı meslek hastalıkları ve kazaları incelemiştir. Kendisinden sonra yapılan çalışmalara yol gösterici olmuş ve meslek hastalıkları, iş kazaları ve çalışma koşullarıı inceleyen ergonomi kavramı ortaya çıkmışıı (Behar, 2007).

Ergonomi terimi Polonyalı bilim adamı Wojciech Bogumil Jastrzebowski tarafından Yunanca iş anlamına gelen "ergo" ile prensipler, kanunlar anlamına gelen "nomos" adlı iki kelimenin birleşiminden oluşturulmuş ve modern bilim literatürüne kazandırılmıştır (Çiçek ve Çağdaş, 2019). Ergonomi terimi Türk Dil Kurumu tarafindan Türkçe'ye "işbilim" olarak geçmesine karşıllık ergonomi terimi daha yaygın kullanılmaktadır.

\subsection{Ergonominin Önemi ve Faydaları}

İnsanların anatomik ve antropometrik özelliklerini, fiziksel kapasitelerini ve toleranslarını göz önüne alarak, iş ortamındaki tüm faktörlerin etkisi ile sistem verimliliğini arttırarak insan-makine-ortam uyumunun sağlanması üzerine çalışan bilimsel bir yaklaşım olan ergonominin başlıca faydaları;

- İnsan sağlığını koruyarak güvenlik seviyesini arttırmak,

- İnsanın hata yapma olasılığını azaltmak,

- Maliyeti azaltmak için tasarım ve operasyonlar üzerine çalışmalar yapmak,

- Etkili ve düzgün bir iletişim kurmak,

- İşlerin süreçlerini inceleyerek işin daha kolay yapılabilmesini sağlamak, 
- Hızlı öğrenme imkânı sunmak,

- Daha fazla stabilite sağlamak,

- Yeni tasarımlara olan ihtiyacı azaltmak,

- İş akışını düzenleyerek arıza veya duraksama zamanlarını azaltmaktır.

\subsection{Tarihçe}

Ergonominin ilk temellerinin; eski Yunan medeniyeti olan Helen uygarlığında M.Ö. 5. Yüzyılda ergonomik prensiplerle tasarlanan çalışma yerleri ve malzemelere ulaşılmasıyla atıldığı düşünülmektedir. Benzer şekilde M.Ö. 200'de Çin Seddi yapımında çalışan işçilerin performanslarının değerlendirilmesi için bir çalışmanın da yapıldığı görülmüştür. M.S. 3. Yüzyılda Konstantin işçilerin dinlenmesi için pazar gününü tatil ilan etmişstir.

Leonardo Da Vinci tarafından 1500'lü yıllarda işçi hareketleri üzerine çalışılmıştır. Taylor ise 1750-1800 yılları arasında işçi verimliliği üzerine çalışarak çeşitli el aletleri geliştirmiştir. 1800 yılında Almanya'da dokuma ve iplik atölyelerinde iş verimliliğini ve etkinliğini arttırmak maksadıyla modernizasyon çalışmaları yapılmıştır.

İşçi sağlı̆̆ını konu alan ilk konferans İsviçre'de 1906 yılında gerçekleştirilmiştir. Bay ve Bayan Gilbreth 1910 yılında iş ve zaman etüdü üzerine çalışarak bu kavramları geliştirmişler ve ergonomik yaklaşımın öncüleri olmuşlardır. 1910 yıllarında Douglas, çalışanları iş başında inceleyerek enerji ölçümleri yapmış ve geliştirdiği model ile iş sürelerini belirlemiştir. 1913 y1lında endüstriyel etkinliklerde psikoloji üzerine çalışmalar yürütülmeye başlanmıştır. Henry Ford'un 1923 yılında ortaya koyduğu seri üretim kavramı ile üretim esnasında işçilerin performansının arttırılması ve üretimin geliştirilmesine yönelik çeşitli çalışmalar yapılmıştır. 1924 yılında çalışanların fiziksel ve psikolojik olarak dinlenmesi maksadıyla Türkiye'de hafta tatili kanunu kabul edilmiştir. 1930 yılında sağlıklı yaşamak için gereken önlemleri ifade eden ve milletin sağlığına zarar veren bütün hastalıklarla mücadele ederek sağlıklı bir nesil yetiştirmek için Türkiye'de Hıfzıssıhha kanunu kabul edilmiştir. Cambridge Üniversitesinde 1932 yılında psikolojinin önemini arttıran "Deneysel Psikoloji Laboratuvarı" kurulmuştur. İngiltere'de işçi yorgunluğunun sebeplerini belirlemek maksadıyla I. Dünya Savaşı yıllarında yorgunluk araştırmaları kurulu kurulmuştur. II. Dünya savaşında yeni makinelerin kullanılmaya başlaması ile insan-makine etkileşimi önemli oranda artmıştır. Ancak bu etkileşimin artmasına rağmen bu alanla ilgili çalışmaların yapılmaması nedeniyle birçok işçi hayatını kaybetmiştir. 1900'lü yılların başından itibaren meydana gelen gelişmeler ve yapılan çalışmalar incelendiğinde işin, işin yapılması için gerekli malzemelerin ve iş ortamının işçi ile uyum içerisinde diğer bir deyişle işçinin fiziki ve psikolojik olarak konforlu hareket edebilecek şekilde çalışmasının önemini göz önüne sermektedir.

1940`larda John Hopkins ve Princeton üniversitelerinin destekleriyle yapılan çalışmalarda İnsan Faktörü Mühendisliği literatüre kazandırılmıştır. İkinci Dünya Savaşı ile yeni makine ve silah sistemleri ihtiyacı doğmuştur. Makine, insan faktörleri dikkate alınarak dikkat, karar verme gibi faktörler anahtar faktör haline gelmiştir. Mühendis ve diğer çalışanların uygun olmayan şartlarda çalıştırılması; savaştan sonra görev ve ortamın insan şartlarına göre düzenlenmesi gerektiğini ortaya koymuştur. 1943 yılında Alphonse Chapanis tarafından uçak kokpit kontrolleri üzerine çalışılarak pilot hatalarının azaltılabileceği gösterilmiştir. Türkiye'de 1945 yılında Çalışma Bakanlığı, 1949 yılında İngiltere’de Ergonomic Research Society, 1953 yılında Almanya'da Ergonomi Derneği kurulmuştur.

İkinci Dünya Savaşı'nın yıkıcı etkileri sebebiyle işçilerin uzun süreler boyunca çalışması, iş tanımının ve ortamının çalışmaya elverişli şartlara göre düzenlenmesi gerekliliğini ortaya çıkarmıştır. 1949 yılında Murrell tarafından Oxford Üniversitesinde bilim insanlarının görüşmeleri sonucunda ergonomi bilimdalı olarak kabul edilmiştir. Stockholm'de Londra'da 1961 yılında uluslararası alanda kabul gören ergonomik kurul kurulma kararı alınmıştır.

1960'ların sonlarına doğru İTÜ ve Çalışma Bakanlığı Türkiye'de ergonomi alanında incelemelere başlamışlardır. Fakülte ve yüksekokullarda iş güvenliği, işçi sağlığı ders olarak okutulmaya başlamış, İstanbul Teknik Üniversitesinde 1969'da "İşbilim", 1971 'de Orta Doğu Teknik Üniversitesinde "Human Factors Engineering" adı altında ergonomi dersi verilmeye başlanmıştır. 1975 yılında yurtdışından ithal edilen çeşitli araç ve gereçler ile ergonomi laboratuvarı kurulmuştur. 1980 yılında endüstri mühendisliği öğrencilerinin alanda yaptıkları araştırmaları analiz edebilmek amacıyla sempozyumlar düzenlenmiştir. 1980'li yıllarda İzmir Dokuz Eylül Üniversitesi ve İzmir Batı Alman Kültür Ataşeliği girişimleri ile ergonomi sempozyumları çeşitli yıllarda tertip edilmiştir. Ayrıca Milli Prodüktivite Merkezi'nin katkılarıyla 1987 yılından itibaren çeşitli üniversitelerin ev sahipliğinde bulunduğu ergonomi kongreleri iki yılda bir düzenlenmeye devam edilmektedir (Köksüz, 2019). Endüstriyelleşmenin ülkemizdeki öncülüğünü yapan otomotiv ve tekstil sektöründeki fabrikaların haricinde kurulan diğer sektörlere ait üretim tesislerinin de gelişen teknolojiye hızlı ayak uydurması ile birlikte 2000 yılı ve sonrası kurulan fabrikalarda ergonomik kurallara uyulması yönünden 
geliş̧meler gözlemlenmektedir. Bu sayede üretim kapasitesi artmakta, işin insana insanında işe uygun olması sağlanarak iş sağlı̆̆ ve güvenliğinin oluşturulmasına yönelik olumlu gelişmeler sağlanmaktadır.

\section{Askeri Alanda Ergonomi}

Ergonomi biliminin iş, insan ve makine arasındaki uyumla doğrudan bağlantılı olduğu düşünüldüğünde kendine özgü malzeme ve ekipmanlar ile donatılmış bir alan olan askeri ergonominin spesifik olarak incelenmesi gerekmektedir. Bu alanda çalışan işçiler askeri personel olarak nitelendirilmiştir. Askeri personelin ihtiyaç duyduğu en uygun, konforlu ve kullanışlı tasarımların yapılmasında ergonomi faktörü büyük rol oynamaktadır.

Denizaltı, hücumbotu, askeri gemi gibi sınırlı alana sahip araçların tasarımında; ergonomik ve antropometrik çalı̧maların yapılması, personelin performansının arttırılması ve savaşma performanslarının yükseltilmesi için gereklidir. Personelin özellikleri dikkate alınarak yetenekleri, eksik yönleri ve ihtiyaçları doğrultusunda, kullanılacak çalışma ortamı, araç ve gereçler ergonomik ve antropometrik kurallara uygun olarak düzenlenmelidir. Çok sayıda personelin belirli süre boyunca birlikte yaşamını idame ettirebilmesinin zorunlu kılındığı, kısıtlı alanlarda iç mekân tasarımlarında personelin fizyolojik ve psikolojik ihtiyaçlarını karşılaması gerektiğinden ergonomi ilkelerine dayanan özel tasarımlara ve çözümlere ihtiyaç duyulmaktadır. Kısıtlı alandan oluşan ve bu alanı etkili şekilde kullanarak personelin çalışma ve yaşam hacimlerini en iyi şekilde kullanabilecek operasyon kısmı, beslenme alanı, dinlenme alanı gibi bölümler ile acil durumlarda personelin hızlı bir şekilde görevinin başına geçebileceği tasarımlar yapılmalıdır (Kılıç, 2020).

Savaş gemisi, hücumbotu gibi araçlarda personelin performansının ve sağlığının en üst düzeyde tutulabilmesi maksadıyla aydınlatma, iklimlendirme, titreşim ve gürültü, görev analizi, yerleşim gibi faktörler incelenmelidir. Personel yaşamını idame ettirirken sergileyeceği performans bu faktörlere bağlıdır. Bu araçlarda yaşayan personelin sağlığı için titreşim ve gürültünün düzeyi kabul edilebilir uygun seviyelere indirilmeli ve personelin sağlığı için bu seviye korunmalıdır. Aksi taktirde görevini icra eden veya görev dışı istirahat eden personel için verimsiz bir ortam oluşacaktır. İklimlendirme konusunda ortamın soğuk ve sıcak olması personeli doğrudan etkilemekte olup uygun düzeyde tutulması askeri savaş etkinliğini doğrudan etkilemektedir. Görev analizi yapılarak askerler için uygun tasarımlar ile personelin rahat çalışabileceği ve hareket edebileceği alanın oluşturulması sayesinde personelin iyi performans sergilemesi sağlanacaktır (Kılıç, 2019).

Askeri kara araçlarının en temel görevlerinden birisi içerisindeki personeli dış tehditlerden korumaktadır. Bu görevin sağlanması esnasında personelin kullanacağı silah sistemleri, işletim sistemlerinin kullanım kolaylığının sağlanması için araç içi sistem tasarımı büyük önem taşımaktadır. Ayrıca araç içindeki personelin soğuk ve sıcak hava şartlarında görevlerini icra edebilmesi için yeterli aydınlatmalı, iklimlendirmeli alanlar ile erişilebilir kontrol panallerine sahip kullanıcı dostu tasarımlara ihtiyaç duyulmaktadır. Örneğin çok sıcak hava şartlarında tankın veya zırhlı personel taşıyıcının içinde görevini icra eden personelin yaşam ortamının insan fizyolojisine uygun olan standartlarda olması personelin muharebe sahasındaki performanslarını etkilemektedir (Kaya ve Erden, 2019).

Askeri araçlarda değerlendirilmesi gereken bir başka faktörde gürültü düzeyidir. Mesleki gürültüye en sık maruz kalan ve doğrudan etkilenen askeri sınıflara örnek olarak pilot, tankçı, topçu, piyade gibi sınıflar verilebilir. Silahlı Kuvvetler bünyesinde görev alan helikopter ve jet pilotları; top, tank, havan, roket vb. silahları kullanan personel mesleki gürültüye doğrudan maruz kalmaktadır. Gürültü seviyesinin yüksekliği personelin atış esnasındaki performanslarını etkilemektedir. Diğger taraftan gürültü faktörünün uzun dönemde meydana getireceği sağlık sorunları sebebiyle de oluşan gürülttü değerleri incelenmeli ve tasarım esnasında gürültüyü azaltıcı tedbirler alınarak tasarımlar buna göre yapılmalıdır (İstanbulluoğlu ve Kır, 2016).

Askeri personelin kullandığı teçhizatlar incelendiğinde; personelin görevini yerine getirirken kullandığı kompozit başlık, hücum yeleği, koruyucu ekipmanlar, askeri bot tasarımlarının ergonomik olarak iyileştirmesi personelin sağlığını, performansını doğrudan etkilemektedir. Kritik görevlerde kullanılan sistemler başta olmak üzere, askeri sistemlerin ve ekipmanların tasarımında; kullanım kolaylığı sağlayacak personel ölçülerine göre tasarım yapılması askerlerin performansını üst düzeye çıkaracaktır. Silah sistemlerinde personelin görüş açısı dikkate alınarak yerleştirilecek paneller, ekranlar, göstergeler göz yorgunluğunu azaltarak uzun süreli takip gerektiren sistemlerin kontrolünü kolaylaştırmaktadır. Antropometrik ölçülere göre yerleştirilecek kontrol panelleri ile acil durumlar dışında da personelin süratle tepki vermesi, nişan alabilmesi ve sistem kontrollerini yapmaları sağlanmalıdır. Hataya dayanıklı, sistem bütünlüğünü etkilemeyecek arızaların hızlıca giderilmesini sağlayacak ve tüm kontrol sistemlerinin görülmesini sağlayacak şekilde araç tasarımlarının yapılabilmesine yönelik araçlarda ergonomik ve antropometrik sistem entegrasyonları yapılmalıdır (Helvacılar ve Eldem, 2017). 


\section{Literatür Taraması ve Değerlendirme}

Literatürde askeri alanlarda ergonomi çalışmalarının yapıldığı çok sayıda çalışma bulunmaktadır. Yapılan çalışmaların içerikleri özet halinde bu bölümde incelenmiştir.

Williams ve Simpson tarafından 1976 yılında yapılan çalı̧̧mada sivil ve askeri hava taşımacıllğı operasyonları için kokpit uyarı sistemi tasarımı yapılmıştır. 8 farklı havayolu pilotlarına anket uygulanarak bilgilendirici, dikkat dağıtıcı, rahatsız edici faktörler incelenerek 18 farklı kokpit uyarı sinyali faktörü analiz edilmiştir. Sonuç olarak kokpit sisteminin tasarımı geliştirilerek pilot performansları arttırılmıştır (Williams ve Simpson, 1976).

Doll ve Folds tarafından 1986 yılında yapılan çalışmada Amerika Birleşik Devletleri Hava Kuvvetleri (USAF) askeri uçaklarında işitsel olarak algılanan sinyal toplulukları incelenmiştir. Çok sayıda işitsel sinyalin kullanılması ve standart bir yapının bulunmaması uçuş ekibi ve personelin iş yükünü ve stresini arttırmakta olduğu tespit edilmiştir. Bu neticede sinyal ses yüksekliğinin azaltılarak, konuşma dışında sinyallerin ayırt ediciliğinin arttırılması, standart bir yapının oluşturulması gerektiği sonucuna ulaşılarak sinyal yüksekliği, uyarı sistemleri, maskeleme direnci ve sinyal ayırt ediciliği faktörleri karşılaştırılmış ve tasarım geliştirme çalışması yapılmıştır (Doll ve Folds, 1986).

Mccaig ve Gooderson tarafindan 1986 yılında yapılan çalışmada soğuk ve yağışlı hava şartlarının askeri operasyonları nasıl etkilediği üzerine Güney Atlantik’te görevini icra eden çok sayıda askeri personelden bilgi toplanarak bir araştırma yapılmıştır. Bu araştırmalar neticesinde özellikle olumsuz hava şartlarında koruyucu giysilerin önemi, giysilerin fiziksel uygunluk gereksinimleri ve yük taşıma sınırlamaları incelenerek muharebe ortamındaki etlkilerinin önemi araştırılmıştır (Mccaig ve Gooderson, 1986).

Bishop, Ray ve Reneau tarafından 1995 yllında yapılan çalışmada askeri koruyucu giysilerden endüstriyel koruyucu giysilere kadar olan çalışma ortamlarındaki verimliliği artırmaya yönelik, iş kıyafetleri üzerine araştırmalar yapılmıştır. İş̧i, iş türü incelenerek fiziksel iş performansı hesaplanarak ergonomi sorunlar tespit edilmiştir. Sonuç olarak yaralanmanın, kaza riskinin, ekipman hasarının azaltılmasında ergonomik tasarıma ihtiyaç olduğu belirtilmiştir (Bishop, Ray ve Reneau, 1995).

McDaniel tarafından 1996 yılında yapılan çalışmada insan faktörleri mühendisliğine verilen önemin azalması üzerine gelişen süreç anlatılarak standartlar belirtilmiş ve ergonominin önemi anlatılmıştır. Askeri standartların önemini kaybetmesinin bu alanda olumsuz sonuçlar yaratacağ belirtilerek ergonomik çalışmalarda standartların uygulanması gerektiği sonucuna ulaşılmıştır (McDaniel, 1996).

Strain ve Preece tarafından 1996 yılında askeri sistemlerin tedarik edilmesinde proje yönetimi çalışması ile insan faktörleri entegrasyonu sağlanarak askeri sistemlerin operasyonel etkinliğinin iyileştirilmesi üzerine çalışılmıştır. Geliştirilen faktör entegrasyonu ile askeri arenada değerlendirilmek üzere aday projelerin seçiminde proje yöneticilerine yardımcı olacak yaklaşımlar ortaya konmuştur (Strain ve Preece, 1999).

Penrice tarafından 2000 yılında yapılan çalışmada yüksek performans gerektiren çok görevli savaş uçakları için tek mürettebat üyesine veya iki mürettebat üyesine ihtiyaç olduğunu savunanlar arasında yaşanan tartışmalar değerlendirilmiştir. Tek kişilik veya iki kişilik tasarımlar çeşitli faktörler gözden geçirilerek analiz edilmiş ve tek kişilik koltuk yaklaşımının tercih edilmesi sonucuna varılmıştır (Penrice, 2000).

Tharion ve Obusek tarafindan 2000 yılında yapılan çalı̧̧mada yeni bir prototip olarak geliştirilen piyade savaş ekipmanı sistemi kullanılarak desteksiz olarak hem yüzüstü hem de ayakta durma pozisyonlarının atış etkinliği test edilmiştir. Atış bozukluklarının başlıca nedeni ekipman sertliğinden kaynaklı olduğu ifade edilerek, atıcının hedefi rahat görememesi, kafasını rahat bir şekilde hareket ettirememesi olduğu belirtilmiştir. Tasarlanacak ekipmanlar için askeri operasyonlarda karşılaşılması muhtemel tüm vücut pozisyonlarının hesaba katılarak gerçekleştirilmesi gerektiği sonucuna ulaşılmıştır (Tharion ve Obusek, 2000).

Macledo tarafından 2003 yılında yapılan çalışmada ergonomik yöntemlerin pratik olarak uygulanması ve geliştirilmesinde yeni teknolojilerin kullanılarak insan faktörü üzerinde meydana gelebilecek değişmelerin öngörülerek belirlenmesi gerektiği anlatılmıştır. Ergonomi yöntemlerinin geliştirilmesi veya mevcut yöntemlerin dikkatli bir şekilde uyarlanması, teknolojik uygunlukla yürütülmesi gerektiği vurgulanarak teknolojik devrimin gerekliliğinden bahsedilmiştir (Macledo, 2003). 
Silah tarafından 2005 yılında yapılan çalışmada işçilerin fiziksel boyutları görsel olarak algılama yeteneğini ölçen From Lege testi uygulaması yapılmıştır. Askeri dikimevi konfeksiyon atölyelerinde çalışan bir grup iş̧̧i belirlenerek uygulanan test neticesinde performans kullanma ve fiziksel düşünme yeteneği verilerinin ortalaması ve standart sapmaları hesaplanarak elde edilen veriler eşik sınırlar açısından yorumlanmıştır. Sonuçlar eşik sınırlara göre yorumlanarak çalışanların performans eşik değerleri saptanmıştır. Bu çalışmalar neticesinde giyim, konfeksiyon atölyelerinde personel seçimi için eşik puanların esas alınması önerilmiştir (Silah, 2005).

Endrusick, Gonzalez ve Gonzalez tarafından 2005 yılında yapılan çalışmada ABD askeri kimyasal ve biyolojik koruyucu giysilerin gelişimi ele alınmıştır. Belirli molekülleri geçiren seçici geçirgen zar olan Selectively Permeable Membranes (SPM) teknolojisinin kullanılması ile termal direnç ve buharlaşma direncinin azaltıldığı ve bu sayede sıcak ortamlarda kullanıcı performansının iyileştirildiği sonucuna ulaşılarak yeni koruyucu giysi tasarımları geliştirilmiştir (Endrusick, Gonzalez ve Gonzalez, 2005).

Endrusick, Cole ve Matonich tarafından 2005 yılında yapılan çalışmada soğuk ve ıslak ortamlarda kullanılmak üzere tasarlanmış askeri botun geliştirilmiş tasarımı; 1Sı yalıtımı üzerine simüle edilen ortamda çevresel etkilere maruz burakılarak incelenmiştir. Geliştirilen yeni bot tasarımında ağırlığın fazla olmasına karşın suya dayanıklılığının ve korumasının önceki tasarımlardan daha iyi olduğu görülmüştür (Endrusick, Cole ve Matonich, 2005).

Birrella ve Haslamb tarafindan 2010 yılında yapılan çalışmada askeri sırt çantasının insan yürüyüşüne olan etkisi incelenmiştir. Yapılan çalışmada askeri personel sırt çantasını taşırken ilk olarak vücudun kütle merkezini arkaya doğru kaydırmanın etkisi, ikinci olarak sırt çantasını kütle merkezine yakın taşımanın etkisi incelenmiştir. Ağır yük taşımanın maksimum frenleme kuvveti üzerindeki etkisi tespit edilerek toplam yük ile çantanın taşınma şeklinin yürüyüş performansını doğrudan etkilediği, askeri yük taşıma sistemlerinin tasarım geliştirme çalışmalarında bu faktörlerin incelenmesi gerektiği anlatılmıştır (Birrella ve Haslamb, 2010).

Duncan, Mclellan ve Dickson tarafından 2011 yılında yapılan çalışmada muharebe operasyonlarının yürütüldüğü ortamlarda personel yaralanmaları ve olası ölümleri önlemek maksadıyla askeri bireysel koruyucu ekipmanların performansı incelenmiştir. Ekipmanlarda konfor, işlevsellik, olası tehditlere karşı uygun koruma seviyesinin arttırılarak daha az yük ile uygun ergonomik tasarımın sağlanması gerektiği belirtilmiş̧tir (Duncan, Mclellan ve Dickson, 2011).

Krueger tarafından 2012 yılında yapılan çalışmada askeri üniformaların insani düşünceler üzerine tasarımları incelenmiştir. Askeri üniformaların stil, görünüm, renk vb. gibi özelliklerin psikolojik olarak birçok anlam ifade etmekte olduğu belirtilmiştir. Asker performansını etkileyebilecek, pratiklik, işlevsellik, fayda, rahatlık ve bedensel koruma ile ilgili özellikleri değerlendirilerek üniforma tasarımının ve geliştirilmesinin insan sistemlerine entegrasyonu yaklaşımının önemi anlatılmıştır (Krueger, 2012).

Carr, Wilson ve Laing tarafından 2012 yılında askeri giysi ve teçhizatın tasarımı için antropometrik yöntemler uygulanarak toplam kütlenin azaltılması, maksimum vücut hareketinin sağlanması için çalışılmışıı. Askeri vücut ölçüleri üzerine veriler toplanarak askeri giysiler için uygun vücut boyları özetlenmiştir (Carr, Wilson ve Laing, 2012).

Tutton ve Denton tarafından 2012 yılında yapılan çalışmada askeri yük taşıma ekipmanı geliştirmede insan faktörlerinin rolü, yük taşımanın insan faktörü ilkeleri, sistematik geliştirme yaklaşımlarının kullanımı konuları özetlenmiştir. Sistematik gelişimi desteklemek için bir video aracının kullanımı ile kullanıı ihtiyaçlarının araştırılması sağlanarak uygulama örneği tartışılmıştır (Tutton ve Denton, 2012).

Hamouda, Sohaimi, Zaidi ve Abdullah tarafından 2012 yılında yapılan çalışmada askeri kasklar için hafif, düşük maliyetli ve etkili ekipman arayışında kullanılan modern malzeme ve araçlar araştırılmışıı. Tasarım, üretim ve test prosedürleri üzerine kafa çarpma mekaniği ve kafa travması kriterleri değerlendirilerek ergonomik olarak tasarım geliştirme çalışması yapılmıştır (Hamouda, Sohaimi, Zaidi ve Abdullah, 2012).

Oord, Dresen ve Sluiter tarafından 2012 yılında yapılan çalışmada askeri helikopter mürettebatı için optimal kask tasarımı yapılmıştır. Boyun yükü ve ağırlık ile doğrudan ilişkili faktörler incelenerek kaskın stabilitesi, kaskın uygunluğu ve rahatlığının arttırılması için ergonomik iyileştirmelerle kask tasarımı ve bu tasarım için gereksinimler değerlendirilmiştir (Oord, Dresen ve Sluiter, 2012). 
Kieneke, Graf ve Mass tarafından 2013 yılında yapılan çalışmada insan sağlığını ve kondisyon güvenini etkileyen mekanik titreşimleri azaltmak maksadıyla askeri araç koltuğu süspansiyon sistemi tasarlanmıştır. Tasarlanan bu koltuk süspansiyonu askeri araca entegre edilerek sürücülerin ve mürettebatın konforunun iyileştirilmesi sağlanmıştır (Kieneke, Graf ve Mass, 2013).

Lee, Kim, Jung, Park ve You tarafından 2013 yılında yapılan çalışmada Kore Hava Kuvvetleri pilotlarına uygun oksijen maskesi tasarlamak için sanal uyum değerlendirilmesi yapılmıştır. Pilotların yüzleri taranarak elde edilen veriler ile geliştirilen oksijen maskeleri basınç, rahatsızlık, askeri teçhizata uygunluk açısından prototipler geliştirilmiştir. Ürün geliştirme modellerinde ergonomik çalışmalar yapılarak elde edilen sonuçlar değerlendirilmiştir (Lee, Kim, Jung, Park ve You, 2013).

Czerwińska M. Tarafından 2014 yılında askeri nanomalzeme uygulamaları üzerine çalışılmıştır. Askeri alanda askerlerin korunması, iletişim cihazları, düşman tespiti ve silahlanma için nanomalzemeler kullanılarak faydaları değerlendirilmiş ve oluşabilecek tehditlerin varlığından bahsedilmiştir (Czerwińska M., 2014).

Dagge ve Filguras tarafından 2015 yılında askeri ağırlık taşıma sistemleri için tasarım geliştirme çalışması yapılmıştır. Askeri personel tarafından sırt çantaları ve taşınan yükler incelenmiştir. Yük taşımayı kolaylaştırmak için son teknoloji ile kullanılan çanta imalat ürünlerini geliştiren bir bakış açısı sunulmuştur (Dagge ve Filguras, 2015).

Alppay ve Bayazit tarafından 2015 yılında yapılan çalışmada helikopter uçuş gösterge panellerinin ergonomiye dayalı tasarımı ele alınmıştır. Kullanıcı merkezli veriler toplanarak, arayüz düzenlenerek, prototipleme çalışması yapılmış, üç yeni arayüz tasarımı ile optimum gösterge paneli düzeni geliştirilmiştir (Alppay ve Bayazit, 2015).

Nayak, Wang ve Padhye tarafından 2015 yılında yapılan çalı̧̧ada savunma sistemlerinin etkisini ve verimliliğini arttırmak için elektronik tekstilin askeri uygulamaları özetlenmiştir. Elektronik bileşenlerin askeri uygulamalardaki fayda ve zorlukları incelenerek askeri üniformalara ve aksesuarlara entegre edilebilecek elektronik bileşenler değerlendirilmiştir (Nayak, Wang ve Padhye, 2015).

Aggromito vd. tarafından 2015 yılında yapılan çalışmada askeri helikopter pilotlarının kullandıkları ekipmanların helikopter kazası sırasında askeri pilotlara ve hava mürettebatına olan etkileri incelenmiştir. Simüle edilen bir senaryo üzerinde çarpışma esnasında yaralanma ve hasar seviyeleri değerlendirilerek yolcu için hayatta kalma kabiliyetini arttıran bir ekipman tasarımı önerilmiştir (Aggromito vd., 2015).

Murray vd. tarafından 2016 yılında askeri helikopter uçuşu sırasında helikopter pilotları ve mürettebat üyeleri arasında boyun, omuz kas aktivitesi ve duruşu çalışılmıştır. Helikopter uçuşu sırasında elektromiyografi (EMG) ölçümleri kullanılarak boyun ve omuz kasları üzerindeki fiziksel iş yükü ölçülerek değer aralıkları belirlenmiştir (Murray vd., 2016).

Wu, Ramchurn ve Chen tarafindan 2016 yılında afet müdahalesinde afet alanı hakkında bilgi toplamak, alanın belirsizliğini azaltmak, kısmi gözlenebilirliği yakalamak maksadıyla insan ile İHA ekiplerinin koordinasyonunun sağlanması üzerine çalışılmıştır. Bir afet senaryosu oluşturularak entegre bir yaklaşım önerilmiş̧ir. Bu çalışmada insan ve makine uyumu üzerine durulmuş̧ur (Wu, Ramchurn ve Chen, 2016).

İstanbulluoğlu ve Kır tarafından 2016 yılında Silahlı Kuvvetlerde görev yapan pilot, top, tank, piyade tüfeği, havan, roket vb. silahları ve sistemleri kullanan askeri personellerin gürültüye çok sık maruz kalmalarından dolayı gürültünün faktörünün meydana getirdiği olumsuz etkiler ve sağlı problemleri incelenmiştir. Askeri personelin maruz kaldığ gürültü seviyeleri ile gürültü konusunda ulusal mevzuata yer alan standartlar değerlendirilerek personelin gürültüden korunabilmesi üzerine çalışılmıştır (İstanbulluoğlu ve Kır, 2016).

Zerehsaz, Jin, Ebert ve Reed tarafından 2017 yılında askeri kara araçlarının sürücüleri için göz konumlarının istatistiksel tahmini için bir model geliştirilerek araç içi düzenin oluşturulmasında asker vücut ölçülerini ve teçhizat grupları üzerine çalışılmıştır. Asker nüfusu için göz konumlarının dağılımı ve vücut boyutları tahmin edilerek araç tasarımında uygulanabilirliği gösterilmiştir (Zerehsaz, Jin, Ebert ve Reed, 2017).

Erol ve Çetiner tarafından 2017 yılında sivil ve askeri alanda giyilebilir teknoloji ile akıllı tekstil üzerine akıllı kumaş sensör çeşitleri incelenerek literatür uygulamaları üzerine çalışılmış̧ır. Akıllı tekstil üretim tekniklerine göre sınıflandırılarak kumaş tasarımı ve gelişimi değerlendirilerek bu alanda yapılan uygulamalar incelenmiştir (Erol ve Çetiner, 2017). 
Helvacılar ve Eldem tarafından 2017 yılında deniz araçlarında muhabere sistemlerinin bileşeni olarak kullanılan askeri mesaj işletim sistemi üzerine insan mühendisliği tasarım kriterleri standartları dikkate alınarak bir tasarım çalışması yapılmıştır. Bu tasarım çalışması ile çalışanların performansını arttırmak için görsel kontrol eksiklikleri ve kullanım zorluğu sebebiyle meydana gelebilecek hataları en aza indirebilecek işletim sisteminin geliştirilmesi üzerine çalışılmıştır (Helvacılar ve Eldem, 2017).

Çelikkol tarafından 2017 yılında yapılan çalışmada askeri harekâtlarda önemli bir faktör olan savaş teknolojileri değerlendirilerek askeri havacılık olayları ve kazalarında insan faktörü sebepleri incelenmiştir. Askeri havacılıkta meydana gelen kazalarda yönetimsel hata ve çevresel koşullar dışında insan faktörünün rolünün büyük olduğu ve birincil sebeplerin dikkatsizlik, tedbirsizlik ve bunları yaratan fizyolojik faktörün yorgunluk olduğu belirtilmiştir. Uygun tasarımlar ile dikkatsizlik, tedbirsizlik ve yorgunluk belirtileri azaltılarak sistemin geliştirilmesi anlatılmıştır (Çelikkol, 2017).

Karakoç ve Asal tarafindan 2017 yılında TSK personelinin kullanabileceği giyilebilir askeri bilişim sistemi üzerine çalışılmıştır. Tek er seviyesinde personelin sahada performansını ve kendine olan güvenini artırarak personel zayiatını en aza indirmek amacıyla akıllı cihazların yetenekleri ile GPS, telsiz gibi araçların özellikleri birleştirilerek daha teknik ve teknolojik sisteme geçilebileceği anlatılmıştır (Karakoç ve Asal, 2017).

Bolin vd. tarafından 2017 yılında yapılan çalışmada insansız hava aracının eylemlerini yönlendirmek için önceden belirlenmiş sinir ağları kullanılarak İHA'nın görüş alanı içindeki durumlarını takip ederek hareketlerini kontrol etmek için tasarım geliştirilmiştir. Kameradan alınan video akışları ile analizler neticesinde drone hareketinin kontrolü sağlanmıştır. Bu sayede insan ile makine uyumu sağlanarak İHA hareketlerinin kontrolü araştırılmıştır (Bolin vd., 2017).

Maher, Li, Hu ve Zhang tarafından 2017 yılında yapılan çalışmada GPS'in olmadığı bir ortamda kişi hareketini algılayabilen ve tanımlayabilen İnsan-UAV etkileşimi sistemi geliştirilmiştir. Geliştirilen bu sistem ile İHA'ların kontrolünün insan hareketleri ile gerçekleşmesi sağlanmıştır (Maher, Li, Hu ve Zhang, 2017).

Tseng, Chao, Yau ve Feng tarafından 2018 yılında yapılan çalı̧̧ada askeri coğrafi istihbarat sistemlerinin ergonomik olarak tasarımı yapılmıştır. Simge tipi, boyutu, harita arka plan renkleri değerlendirilerek performansın artması için arayüz tasarlanmıştır. Sonuç olarak radar operatörlerinin iş yükü azaltılarak verimlilik arttırılmıştır (Tseng, Chao, Yau ve Feng, 2018).

Bozdemir tarafından 2018 yılında silah ve insan arasındaki temas ve birleşim noktası olan silah kabzalarının tasarım ve imalatı üzerine bir çalışma yapılmıştır. Uygun bir silah kabzası tasarımında el yorgunluğunun azaltılması, tutma hatları, tetik kontrolü, etkili kullanım için tasarımın yapılması gerektiği ve bu sebeple ergonomik çalışmalara ihtiyaç olduğu belirtilmiştir. Silaha hâkimiyet, güvenli ve doğru atış için incelemeler yapılmıştır (Bozdemir, 2018).

Altuntaş, Dereli ve Özşalap tarafından 2019 yılında havacılık sektöründe F-16 savaş uçaklarında bakım operasyonlarında kolaylık sağlayan ekipman geliştirilerek yeniden tasarımı yapılmıştır. Ergonomik olması, kullanım esnekliği sağlaması ve kullanıcılar dikkate alınarak gerekli iyileştirmeler yapılmış ve ürün geliştirmeye yönelik sistematik olarak gerçek hayat uygulaması gösterilmiştir. $\mathrm{Bu}$ çalışma neticesinde havacılık sektöründe bakım operasyonlarındaki etkinlik ve verimliliğin arttırılması hedeflenmiştir (Altuntaş, Dereli ve Özşalap, 2019).

Kılıç tarafından 2019 yılında yapılan çalışmada askeri araçların iç mekân tasarımı üzerine askeri denizaltılar için ergonomik ilkeler ele alınmıştır. Çok sayıda personelin belirli süreler boyunca yaşamını idame ettirebileceği sınırlı alanlardaki özel tasarımlar incelenmiştir. Personelin ihtiyaçları göz önüne alınarak beslenme, dinlenme, görev alanları gibi kısımların yerleşimi üzerine çalışılmış ve iç mekân tasarımının önemi vurgulanmıştır (Kılıç, 2019).

Tsykunov vd. tarafindan 2019 yılında yapılan çalışmada giyilebilir cihazlar ile drone topluluklarının iniş kontrolünün sağlanması için bir tasarım çalışması yapılarak dört dronedan oluşan bir filonun insan kollarına inmesi için yeni bir sistem geliştirilmiştir. Titreşimli geri bildirimli ışığa duyarlı iniş yastıkları sayesinde insan kollarına dronların inmesi sağlanmıştır. En iyi iniş performansının dokunsal ve görsel geri bildirim kombinasyonuyla elde edildiği görülmüştür. (Tsykunov vd., 2019).

Labazanova, Tleugazy, Tsykunov ve Tsetserukou tarafindan 2018 yılında yapılan çalışmada drone topluluklarının birlikte çalışması için giyilebilir dokunsal cihaz tasarlanmıştır. Kullanıcılar droneların durumunu parmak uçlarında hissederek görsel geri bildirimler ile topluluğun kontrolünü sağlayan değerler alınmıştır. Bu değerler ile drone topluluklarının kontrol edilebilirliği 
sağlanarak çarpışmalar önlenmiş̧ir. Oluşturulan sanal köy ve şehir ortamlarında statik ve dinamik engeller ile teknolojinin yeteneği gösterilmiştir. (Labazanova, Tleugazy, Tsykunov ve Tsetserukou, 2018).

Kaya ve Erden tarafından 2019 yılında askeri kara araçlarında personeli dış tehditlerden koruyabilmek maksadıyla yapılan araç gövde tasarımlarının yetersiz kalması nedeniyle el yapımı patlayıcı ve mayınlara karşı dirençli askeri personel koltuğu tasarımı yapılmıştır. Koltuklarda uygulanan sönümleme sistemleri ile patlama esnasında meydana gelen enerji koltuk tarafından absorbe edilerek personele az bir kısmını aktararak patlamanın etkisi azaltılmaktadır (Kaya ve Erden, 2019).

Muslim, Moch, Ramadhan, Rasyad ve Risya tarafından 2019 yılında askeri sırt çantasının tasarımı, genişliği, yüksekliği, taşıyabileceği maksimum yük ile ergonomik bileşenlerinin en iyi duruma getirebilmesi için vücut, bel, çalışma duruşu ve görev analizleri yapılarak tasarım geliştirilmiştir. Askeri sırt çantaları için boyutlar ve ağırlıklar incelenerek insan faktörüne göre uygunluğu değerlendirilmiş ve askeri sırt çantasının en uygun uzunluk, genişlik, yük ve ergonomik duruş sonuçlarına ulaşılmıştır (Muslim, Moch, Ramadhan, Rasyad ve Risya, 2019).

Ersin, Yaz ve Karhan tarafından 2019 yılında yapılan bu çalışmada nesnelerin interneti (IoT) uygulamaları ile nesnelerin haberleşmesi sağlanarak savunma sanayinde bir uygulama yapılmıştır. İnternet tabanlı mikro denetleyici geliştirme kartı kullanılarak sıcaklık, nem sensörleri, nabız ölçer, GPS modülleri birlikte kullanılarak askerin ve bulunduğu ortam hakkında anlık olarak bilgi alınmaktadır (Ersin, Yaz ve Karhan, 2019).

Park, Choi, Song, Ahn ve Jeong tarafından 2019 yılında yapılan çalışmada askeri araçların arazi koşullarında kullanılmasından kaynaklanan titreşim simüle edilerek titreşime maruz kalma ile dikkat azalması arasındaki ilişki incelenmiştir. Elde edilen sonuçlara göre otomatik algısal dikkat titreşime maruz kalmadan etkilenmezken; bilişsel işlemler arttı̆̆ında titreşimin etkileri önemli hale gelmiştir (Park, Choi, Song, Ahn ve Jeong, 2019).

Özer tarafindan 2019 yılında yapılan çalı̧̧mada hızlı bir şekilde askeri alanda nanoteknoloji uygulamalarına ait girişimin yapılmaması üzerine değerlendirmeler yapılmış ve yaşanan gecikmeler sebebiyle farkındalık vurgusu yapılarak güvenlik perspektifinden tartılışmış ve geleceğe yönelik öngörülerde bulunulmuştur (Özer, 2019).

Deringöz, Danışan ve Eren tarafından 2021 yılında yapılan çalışmada Endüstri 4.0 dönemi ile akıllı üretim sistemlerine geçiş yapılarak askeri ve endüstriyel alanlar başta olmak üzere çeşitli sektörlerde kullanılan 7 farklı akıllı gözlük incelenmiştir. Maliyet, pil ömrü, ergonomik olması gibi kriterler değerlendirilerek en iyi alternatif belirlenmiş̧ir (Deringöz, Danışan ve Eren, 2021).

Müezzinoğlu ve Karaköse tarafından 2021 yılında yapılan çalışmada insan ile İHA etkileşimi ve kontrolü sağlamak için giyilebilir akıllı bir eldiven tasarımı yapılmıştır. Gerçek zamanlı olarak İHA simülasyonu uygulanarak el hareketlerince belirlenen komutlara verdiği tepkiler incelenmiştir (Müezzinoğlu ve Karaköse, 2021).

Walsh tarafindan 2021 yılında yapılan çalışmada askere özel taşınan yüklerin askerlerin yürüyüşüne etkileri incelenmiştir. Yük ve görev özellikleri bakımından veri tabanları taranarak 20 makale incelenerek özeti sunulmuş̧ur (Walsh, 2021).

Kolose, Stewart, Hume ve Tomkinson tarafından 2021 yılında yapılan çalışmada karar ağaçları ve 3 boyutlu vücut tarama verileri ile askeri muhabere kıyafetinin beden tahmini üzerine çalışılmıştır. Ölçüm yöntemi sonucunda gömlek bedeninde doğruluk \%58.1, pantolon bedeninde doğruluk \%61.7 olarak belirlenmiştir. Antropemetrik veriler ile tasarım geliştirme üzerine çalışılmıştır (Kolose, Stewart, Hume ve Tomkinson, 2021).

Gijsbertse, Linssen, Woering ve Catoire tarafindan 2021 y1lında yapılan çalışmada askeri personel engel parkurunda performans gösterirken kişisel koruyucu ekipmanların ve kıyafetlerin ağırlığının fiziksel performansa etkileri incelenmiştir. Kütle ve sertliğin fiziksel performansı olumsuz etkilediği ve fiziksel yükün azaltılarak tasarımın iyileştirilmesi sonucuna ulaşılmıştır (Gijsbertse, Linssen, Woering ve Catoire, 2021).

Looney vd. tarafından 2021 yılında yapılan çalışmada modern askeri sırt çantalarının ABD ordusu askerinin yürüme hızı ve fiziksel etkileri incelenmektedir. Geliştirilen sırt çantası tasarımı ile ağır yüklerin etkileri incelenerek iş yoğunluğu azaltılmakta ve performans arttırılmaktadır (Looney vd., 2021). 
Coltman vd. tarafından 2021 yılında yapılan bu çalışmada askeri vücut zırh sistemlerinin erkek askerlerin antropometrik boyutlarına daha uygun olduğu ve bu sebeple kadın askerlerin vücut zırhlarıyla ilgili yaşadıkları sorunlar incelenmiştir. Vücut zırh tasarımı yapılırken kadın askerlerin antropometrik verileri incelenerek ergonomik olarak uyumu, biçimi ve işlevi sağlayan tasarımların yapılması gerektiği çalışılmıştır (Coltman vd., 2021).

1970’li yıllardan günümüze kadar askeri alanda kullanılan silah, teçhizat ve yardımcı malzemeler ile bu malzemelere ilişkin teknolojik (nanoteknoloji, akıllı sistemler vb.) alanda yapılan 54 adet çalışma incelenmiş ve bu çalışmalar kuvvet ve konu bazlı olarak sınıflandırılmıştır. Bu sınıflandırma yapılırken kullanılan çalışmalara ait bilgiler Tablo 1'de verilmiştir.

Tablo 1. Askeri Ergonomi Hakkında Yapılan Çalışmaların Sınıflandırılması

\begin{tabular}{|c|c|c|c|c|c|c|c|c|c|c|}
\hline \multirow{2}{*}{ Yıl } & \multirow{2}{*}{ Yazar } & \multicolumn{4}{|c|}{ Kuvvet Bazlı Sinıflandırma } & \multicolumn{5}{|c|}{ Konu Bazlı Sınıflandırma } \\
\hline & & Kara & Hava & Deniz & Müşterek & $\begin{array}{c}\text { Askeri } \\
\text { Teknoloji }\end{array}$ & $\begin{array}{l}\text { Giyim, } \\
\text { Kıyafet }\end{array}$ & $\begin{array}{c}\text { Proje ve } \\
\text { Standartlar }\end{array}$ & $\begin{array}{c}\text { Silah, } \\
\text { Teçhizat }\end{array}$ & $\begin{array}{c}\text { Antro } \\
\text { pometri }\end{array}$ \\
\hline 1976 & $\begin{array}{l}\text { Williams ve } \\
\text { Simpson }\end{array}$ & & $\checkmark$ & & & $\checkmark$ & & & & \\
\hline 1986 & Doll ve Folds & & $\checkmark$ & & & $\checkmark$ & & $\checkmark$ & & \\
\hline 1986 & $\begin{array}{l}\text { McCa1g ve } \\
\text { Gooderson }\end{array}$ & & & & $\checkmark$ & & $\checkmark$ & & & \\
\hline 1994 & Bishop vd. & & & & $\checkmark$ & & $\checkmark$ & & & \\
\hline 1996 & McDaniel & & & & $\checkmark$ & & & $\checkmark$ & & \\
\hline 1999 & $\begin{array}{l}\text { Strain ve } \\
\text { Preece }\end{array}$ & & & & $\checkmark$ & & & $\checkmark$ & & \\
\hline 2000 & Penrice & & $\checkmark$ & & & $\checkmark$ & & & & \\
\hline 2000 & $\begin{array}{l}\text { Tharion ve } \\
\text { Obusek }\end{array}$ & $\checkmark$ & & & & & & & $\checkmark$ & \\
\hline 2003 & Macleod & & & & $\checkmark$ & $\checkmark$ & & & & \\
\hline 2005 & Silah & & & & $\checkmark$ & & $\checkmark$ & & & \\
\hline 2005 & Endrusick vd. & & & & $\checkmark$ & & $\checkmark$ & & & \\
\hline 2005 & Endrusick vd. & & & & $\checkmark$ & & $\checkmark$ & & & \\
\hline 2010 & $\begin{array}{c}\text { Birrella ve } \\
\text { Haslamb }\end{array}$ & $\checkmark$ & & & & & & & & $\checkmark$ \\
\hline 2011 & Duncan vd. & & & & $\checkmark$ & & & & $\checkmark$ & \\
\hline 2012 & Krueger & & & & $\checkmark$ & & $\checkmark$ & & & \\
\hline 2012 & Carr vd. & & & & $\checkmark$ & & $\checkmark$ & & $\checkmark$ & \\
\hline 2012 & $\begin{array}{l}\text { Tutton ve } \\
\text { Denton }\end{array}$ & & & & $\checkmark$ & & & & $\checkmark$ & $\checkmark$ \\
\hline 2012 & Hamouda vd. & $\checkmark$ & $\checkmark$ & & & & $\checkmark$ & & $\checkmark$ & \\
\hline 2012 & Marieke vd. & $\checkmark$ & $\checkmark$ & & & & $\checkmark$ & & $\checkmark$ & $\checkmark$ \\
\hline 2013 & Kieneke vd. & $\checkmark$ & & & & $\checkmark$ & & & & \\
\hline 2013 & Lee vd. & & $\checkmark$ & & & & & & $\checkmark$ & $\checkmark$ \\
\hline 2014 & $\begin{array}{c}\text { Czerwińska } \\
\text { M. }\end{array}$ & & & & $\checkmark$ & $\checkmark$ & & & & \\
\hline 2015 & $\begin{array}{l}\text { Dagge ve } \\
\text { Filguiras }\end{array}$ & & & & $\checkmark$ & $\checkmark$ & & & & \\
\hline 2015 & $\begin{array}{l}\text { Alppay ve } \\
\text { Bayazit }\end{array}$ & $\checkmark$ & $\checkmark$ & & & $\checkmark$ & & & & \\
\hline 2015 & Nayak vd. & & & & $\checkmark$ & $\checkmark$ & $\checkmark$ & & & \\
\hline 2015 & $\begin{array}{l}\text { Aggromito } \\
\text { vd. }\end{array}$ & $\checkmark$ & $\checkmark$ & & & & & & $\checkmark$ & \\
\hline 2016 & Murray vd. & $\checkmark$ & $\checkmark$ & & & & & & & $\checkmark$ \\
\hline 2016 & Wu vd. & & $\checkmark$ & & & $\checkmark$ & & & & \\
\hline 2016 & $\begin{array}{c}\text { İstanbulluoğl } \\
\text { u ve Kır }\end{array}$ & & & & $\checkmark$ & & & & & $\checkmark$ \\
\hline 2017 & Zerehsaz vd. & $\checkmark$ & & & & & & & & $\checkmark$ \\
\hline 2017 & $\begin{array}{l}\text { Erol ve } \\
\text { Çetiner }\end{array}$ & & & & $\checkmark$ & & $\checkmark$ & & & \\
\hline 2017 & $\begin{array}{l}\text { Helvacilar ve } \\
\text { Eldem }\end{array}$ & & & $\checkmark$ & & $\checkmark$ & & & & \\
\hline 2017 & Çelikkol & & $\checkmark$ & & & & & $\checkmark$ & & \\
\hline 2017 & $\begin{array}{c}\text { Karakoç ve } \\
\text { Asal }\end{array}$ & & & & $\checkmark$ & $\checkmark$ & $\checkmark$ & & & \\
\hline 2017 & Bolin vd. & & $\checkmark$ & & & $\checkmark$ & & & & \\
\hline 2017 & Maher vd. & & $\checkmark$ & & & $\checkmark$ & & & & \\
\hline 2018 & Tseng vd. & & & & $\checkmark$ & $\checkmark$ & & & & \\
\hline 2018 & Bozdemir & $\checkmark$ & & & & & & & $\checkmark$ & \\
\hline 2019 & Altuntaş vd. & & $\checkmark$ & & & & & & $\checkmark$ & \\
\hline 2019 & Onur Kılıç & & & $\checkmark$ & & & & $\checkmark$ & & $\checkmark$ \\
\hline 2019 & Tsykunov vd. & & $\checkmark$ & & & & $\checkmark$ & & & \\
\hline 2019 & $\begin{array}{c}\text { Labazanova } \\
\text { vd. }\end{array}$ & & $\checkmark$ & & & & $\checkmark$ & & & \\
\hline
\end{tabular}


Tablo 1 (devam). Askeri Ergonomi Hakkında Yapılan Çalışmaların Sınıflandırılması

\begin{tabular}{|c|c|c|c|c|c|c|c|c|c|c|}
\hline \multirow[b]{2}{*}{ Yil } & \multirow[b]{2}{*}{ Yazar } & \multicolumn{4}{|c|}{ Kuvvet Bazlı Sınıflandırma } & \multicolumn{5}{|c|}{ Konu Bazlı Sınıflandırma } \\
\hline & & Kara & Hava & Deniz & Müşterek & $\begin{array}{c}\text { Askeri } \\
\text { Teknoloji }\end{array}$ & $\begin{array}{l}\text { Giyim, } \\
\text { Kıyafet }\end{array}$ & $\begin{array}{l}\text { Proje ve } \\
\text { Standartlar }\end{array}$ & $\begin{array}{c}\text { Silah, } \\
\text { Teçhizat }\end{array}$ & $\begin{array}{c}\text { Antro } \\
\text { pometri }\end{array}$ \\
\hline 2019 & $\begin{array}{l}\text { Kaya ve } \\
\text { Erden }\end{array}$ & $\checkmark$ & & & & & & $\checkmark$ & & \\
\hline 2019 & Muslim vd. & $\checkmark$ & & & & & & $\checkmark$ & $\checkmark$ & $\checkmark$ \\
\hline 2019 & Ersin vd. & & & & $\checkmark$ & $\checkmark$ & & & & \\
\hline 2019 & Park vd. & $\checkmark$ & & & & & & & & $\checkmark$ \\
\hline 2019 & Özer & & & & $\checkmark$ & $\checkmark$ & & $\checkmark$ & & \\
\hline 2021 & Deringöz vd. & & & & $\checkmark$ & & $\checkmark$ & & & \\
\hline 2021 & $\begin{array}{l}\text { Müezzinoğlu } \\
\text { ve Karaköse }\end{array}$ & & & & $\checkmark$ & & $\checkmark$ & & & \\
\hline 2021 & Walsh & $\checkmark$ & & & & & & & & $\checkmark$ \\
\hline 2021 & Kolose vd. & $\checkmark$ & & & & & & & & $\checkmark$ \\
\hline 2021 & Gijsbertse vd. & & & & $\checkmark$ & & $\checkmark$ & & $\checkmark$ & $\checkmark$ \\
\hline 2021 & Looney vd. & $\checkmark$ & & & & & & & $\checkmark$ & $\checkmark$ \\
\hline
\end{tabular}

Yapılan inceleme neticesinde askeri ergonomi alanında yıllara sâri olarak kuvvet bazlı akademik çalışma sayıları Şekil 1'de gösterilmiş, bu çalışmaların hangi kuvvete ait ihtiyaçlar üzerine yapıldığını gösteren yüzdeler ise Şekil 2'de sunulmuştur. Daha sonra aynı şekilde bu çalışmaların ergonomi biliminin ilgi alanına giren konulardaki yıllara ait sayısı ve ağırlığı üzerine çalışılarak Şekil 3 ve Şekil 4'te verilen grafikler elde edilmiştir.

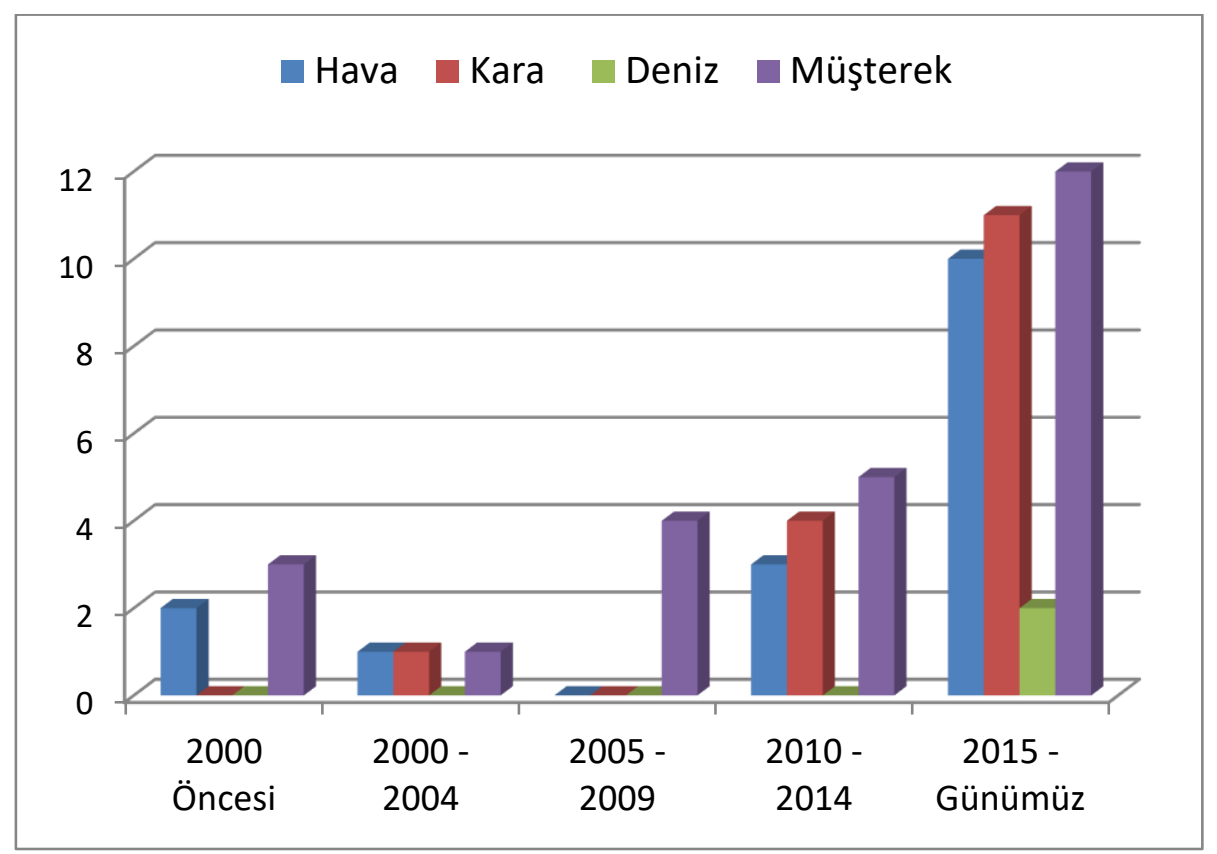

Şekil 1. Kuvvet Bazlı Sınıflandırma

Askeri alanda kuvvet bazlı sınıflandırma yapılarak yıllara göre literatür incelendiğinde;

- 2000 yılı ve öncesinde 2 hava, 3 müşterek olmak üzere toplam 5,

- 2000-2004 yilları arasında 1 hava, 1 kara ve 1 müşterek olmak üzere toplam 3,

- 2005-2009 yılları arasında 4 müşterek olmak üzere toplam 4,

- 2010-2014 yılları arasında 3 hava, 4 kara ve 5 müşterek olmak üzere toplam 12 ,

- 2015 yılı ve günümüz itibariyle 10 hava, 11 kara, 2 deniz ve 12 müşterek olmak üzere 35 çalışma tespit edilmiştir. 

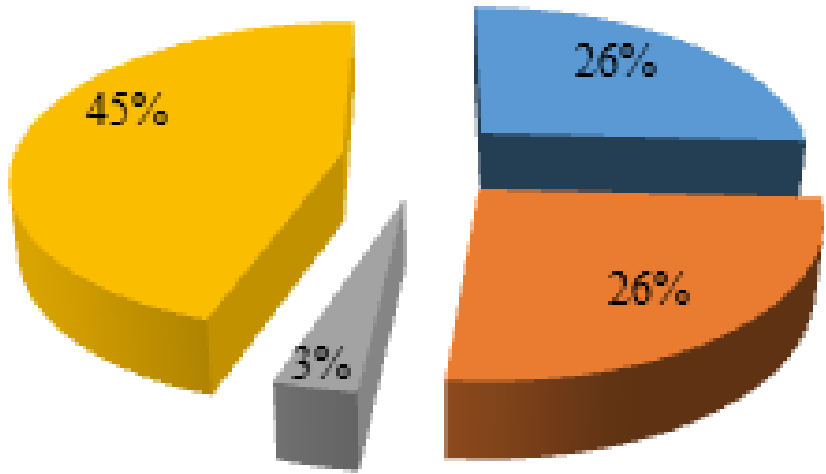

- Kara

- Hava

Deniz

- Misșterek

Şekil 2. Kuvvet Bazlı Sınıflandırma

Literatür incelendiğinde askeri alanda yapılan çalışmaların beklenenin aksine sayısının az olduğu ve \%45 oranında tüm kuvvetlere hitap edecek alanlarda yapıldığg tespit edilmiştir. Tek başına hava ve kara kuvvetleri ilgi alanlarını kapsayan çalışmalar \%26‘lık dilimleri kapsarken sadece deniz kuvvetleri ile ilgili çalışmalar \%3 oranındadır. Günümüzde yapılan deniz yetki sınırı anlaşmaları göz önüne alındığında bu alanda yapılacak çalışmaların giderek önem kazanacağı ve deniz kuvvetleri alanında yapılacak ergonomi çalışmalarının artacağı düşünülmektedir. Kara ve hava kuvvetleri için dar ve sınırlı alanlarda yapılan tasarım çalışmalarının deniz kuvvetleri içinde geçerli olduğu ve bu alanda denizaltı, savaş gemisi, hücumbotu gibi askeri araçlarda yürütülebilecek çalışmalarla deniz kuvvetlerindeki ergonomi çalışmalarının artabileceği değerlendirilmektedir.

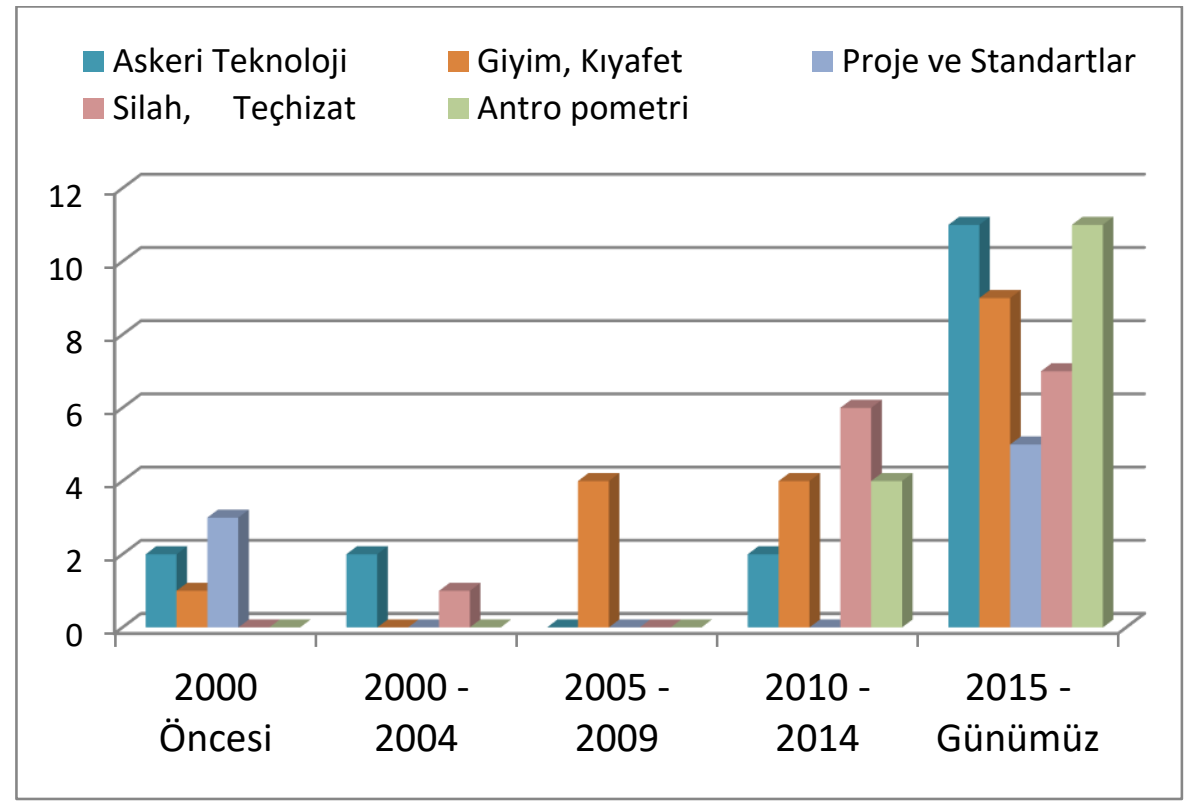

Şekil 3. Konu Bazlı Sınıflandırma

Askeri alanda konu bazlı sınıflandırma yapılarak yıllara göre literatür incelendiğinde,

- 2000 yılı ve öncesinde askeri teknoloji sınıfında 2, giyim, kıyafet sınıfında, proje ve standartlar sinıfında 3,

- 2000-2004 yılları arasında askeri teknoloji sınıfında 2, silah ve teçhizat sınıfında 1,

- 2005-2009 yılları arasında giyim, kıyafet sinıfinda 4,

- 2010-2014 yılları arasında askeri teknoloji sınıfında 2, giyim, kıyafet sınıfında 4, silah, teçhizat sınıfında 6 ve antropometri sinifinda 4 ,

- 2015 yılı ve günümüz itibariyle askeri teknoloji sınıfında 11, giyim, kıyafet sınıfında 9, proje ve standartlar sınıfında 5, silah, teçhizat sınıfında 7 ve antropometri sınıfında 11 çalışma tespit edilmiştir. 

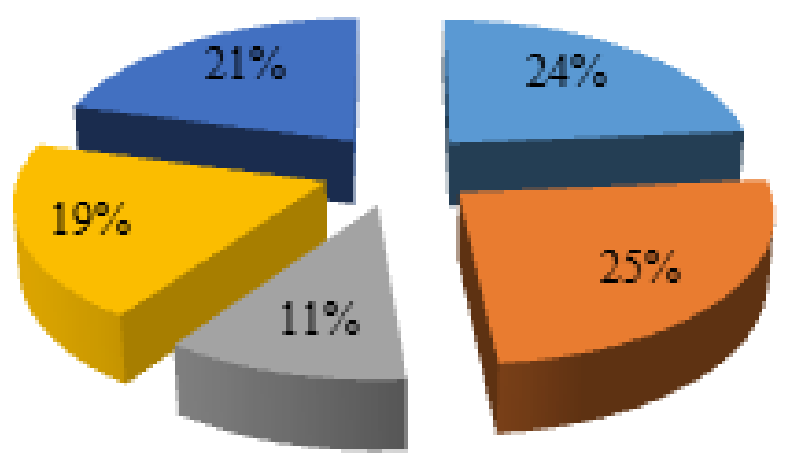

- Askeri Teknoloji

n Giyim, Kiya fet

- Proje ve Standartlar

Silah, Teçhizat

Antropometri

Şekil 4. Konu Bazlı Sınıflandırma

Kuvvet ayrımı olmaksızın çalışmalar askeri teknoloji, giyim, kıyafet, proje ve standartlar, silah ve teçhizat, antropometri konuları olarak 5 başlık altında sınıflandırılmıştır. Bu sınıflandırmada \%25 ile askeri giyim ve kıyafetler üzerindeki çalışmaların ilk sırayı aldığı görülmektedir. Bu konuyu sırasıyla \%24 ile askeri teknoloji faaliyetlerinin, \%21 ile antropometri, \% 19 ile silah ve teçhizat içerikli faaliyetlerin takip ettiği tespit edilmiştir. Son sırada ise \%11 ile proje ve standartlara ilişkin çalışmalar yer almaktadır. Gelişen teknolojik koşullar dikkate alındığında askeri teknoloji faaliyetlerinin daha ön planda tutularak akıllı teknolojiler ve nanoteknoloji hamleleri ile askeri alanda ergonomi projesi çalışmalarının sayısında artış olacağı öngörülmektedir.

Yapılan çalışmaların yıllar içerisindeki dağılımını daha iyi inceleyebilmek için kuvvet ve konu bazlı sayıları bütünleşik olarak Şekil 5'te gösterilmiştir.

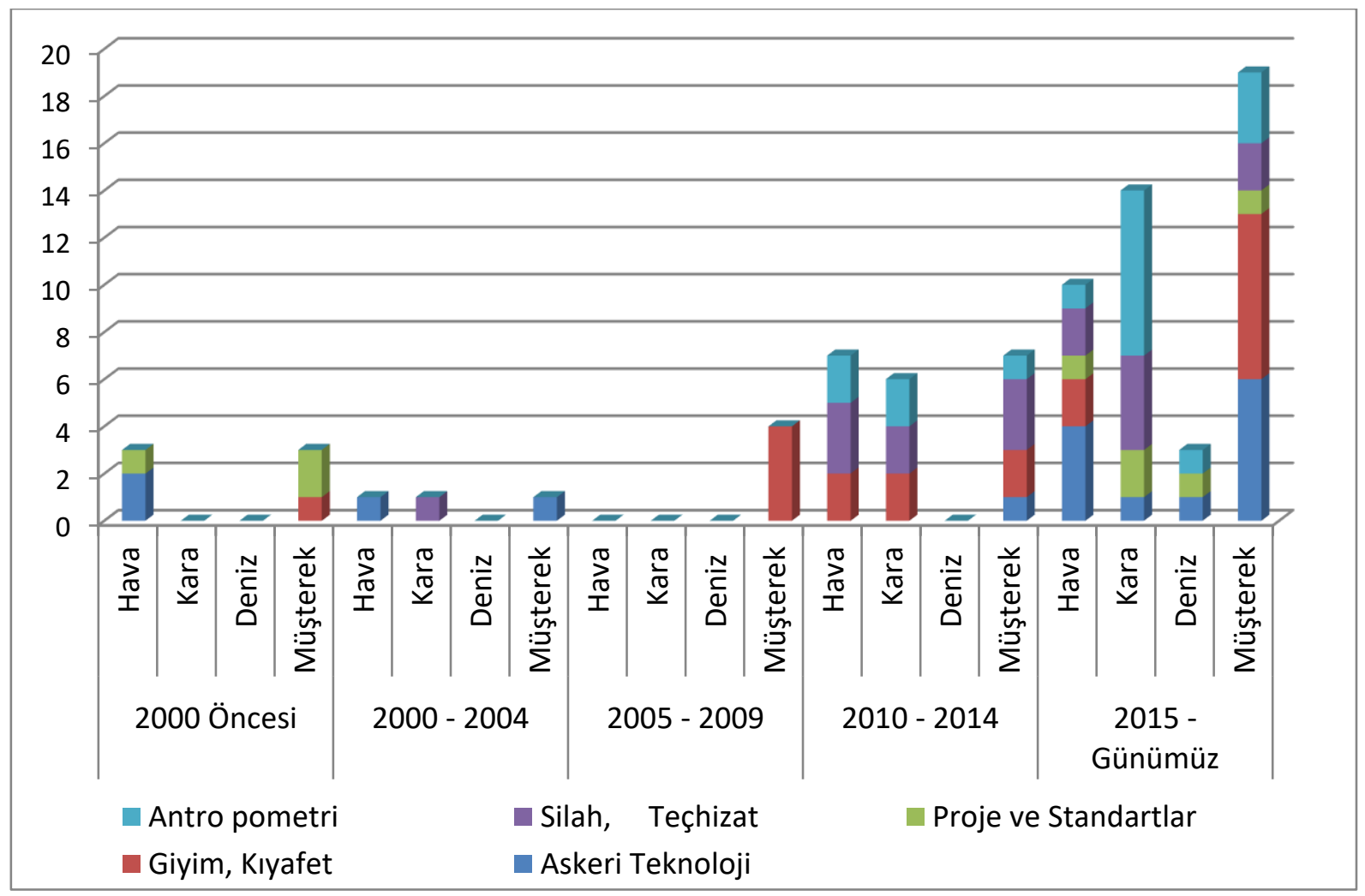

Şekil 5. Konu ve Kuvvet Bazlı Sınıflandırma

Askeri alanda yapılan çalışmalar konu ve kuvvet bazlı sınıflandırılarak birlikte incelendiğinde 2010 yılı öncesinde çalışmaların az olduğu, 2010 yılı ve sonrası itibariyle bu çalışmaların hız kazanarak arttığı görülmektedir. Özellikle kara, hava ve deniz kuvvetlerini içeren müşterek çalışmalar tek bir kuvvet için yapılan çalışmalardan fazladır. Deniz kuvvetleri için yapılan çalışmaların az olduğu görülmektedir. Kara kuvvetlerinde yer alan askeri araçlar veya hava kuvvetlerindeki sınırlı alan problemleri deniz kuvvetleri içinde geçerli olmaktadır ve bu sebeple deniz kuvvetlerinde daha fazla çalışma yürütülebilir. Müşterek çalışmalar dışında üç kuvveti ayrı ele alırsak en fazla çalışma kara kuvvetlerinde yapılmıştır. İkinci sırada hava kuvvetleri ve son sırada deniz kuvvetleri yer 
almaktadır. Bunun nedeninin ülkelerin kara kuvvetlerinde çalışan personel sayısının hava ve deniz kuvvetlerinde çalışan personel sayısına göre daha fazla olması ve yapılacak iyileştirmelerin daha fazla kişiye etki etmesi olduğu değerlendirilmektedir.

\section{Sonuç ve Yorumlar}

$\mathrm{Bu}$ çalışmada askeri alanda yapılan ergonomi çalışmaları araştırılarak literatür incelemesi yapılmıştır. Yapılan literatür incelemesindeki amaç; günümüze kadar yapılan askeri alanlardaki ergonomi çalışmalarını inceleyerek problem sahalarını belirleyip bu alanda yeni çalışmalar yapacak araştırmacılar için literatürü özet halinde sunmaktır. İleriye yönelik yapılacak akademik çalışmalarda araştırmacılara yön göstermek hedeflenmektedir. Bu hedefe ulaşabilmek amacıyla kuvvet bazlı ve konu bazlı olarak iki ayrı sınıflandırmaya gidilmiştir.

Literatür incelendiğinde askeri alanda yapılan çalışmaların beklenenin aksine sayısının azlığ ve \%45 oranında tüm kuvvetlere hitap edecek alanlarda yapıldığı tespit edilmiştir. Tek başına hava ve kara kuvvetleri ilgi alanlarını kapsayan çalışmalar \%26'şarlık dilimleri kapsarken sadece deniz kuvvetleri ile ilgili çalışmalar \%3 oranında olup bu alandaki eksiklik dikkat çekici olarak göze çarpmaktadır. Kuvvet ayrımı olmaksızın çalışmaların konu kapsamları incelenerek yapılan analizde ise \%25 ile askeri giyim ve kıyafetler üzerindeki çalışmaların ilk sırayı aldığ 1 ve bu sırayı \%24 ile askeri teknoloji faaliyetlerinin, \%21 ile antropometri, \% 19 ile silah ve teçhizat içerikli faaliyetlerin takip ettiği tespit edilmiştir. Son sırada ise $\% 11$ ile proje ve standartlara ilişkin çalışmalar yer almaktadir.

Kara kuvvetlerinde yapılan çalışmalar deniz ve hava kuvvetlerindeki çalışmalardan fazladır. Bu durumun en büyük sebebi kara kuvvetlerinde yer alan personel sayısının diğer kuvvetlerden fazla olmasıdır. Diğer bir açıdan incelenen makalelerde kişisel tasarımla alakalı yapılan çalışmaların diğer kategorilere göre sayıca daha fazla olduğu ve bu tasarımların yoğunlukla kara kuvvetlerine ait çalışmalarda yapıldığı görülmektedir. Bu iki durum kara kuvvetlerinde yapılan çalışmaların sayıca fazlalığının nedenine 1 şı tutmaktadır.

Deniz ve hava kuvvetlerinde yapılacak çalışmaların da en az kara kuvvetleri çalışmaları kadar önemli olduğu ve bu alanlarda daha fazla çalışma yapılması gerektiği değerlendirilmektedir. Gelecekte deniz ve hava kuvvetleri bünyesinde yapılacak çalışmalarda, personelin çalışma alanı düşünüldüğünde gemi, denizaltı ve kokpit gibi ortamlara ait iyileştirme ve yaşam standartlarını yükseltmek amacıyla askeri ergonomi konularına yönelinebilinir. Aynı şekilde operasyonlardaki başarının artırılması ve dar alandan etkin bir şekilde faydalanılması göz önünde bulundurularak askeri personelin bu araçlarda kullanacağı silahların ergonomik tasarımlarına yönelik çalışmalar yürütülebilir. Ayrıca günümüzde savaş ortamlarında keşif ve gözetleme görevleri için sıkça kullanılan küçük İHA'ların personel tarafından rahat kullanımı ve taşınmasına yönelik insan-makine uyumu üzerine çalışmalar arttırılabilir ve teknolojinin hızla gelişmesi ile ülkelerin askeri harcamalara yönelik ayırdığı bütçeler dikkate alındığında askeri giyim, teknoloji ve silah, teçhizata yönelik araştırmaların kapsamı genişletilebilir. Yapılacak bu çalışmalar neticesinde askeri personelin antropometrik ölçümlere ve standartlara uygun silah, teçhizat, kıyafet ve donanımlar ile iş yaşamındaki performansının artması, insan ve malzeme uyumunun maksimum seviyede tutulmaya çalışılması sağlanılabilir.

\section{Kaynakça}

Aggromito, D., Thomson, R., Wang, J., Chhor, A., Chen, B., \& Yan, W. (2015). Effect of body-borne equipment on injury of military pilots and aircrew during a simulated helicopter crash. International Journal of Industrial Ergonomics, 50, $130-142$.

Alppay, C., \& Bayazit, N. (2015). An ergonomics based design research method for the arrangement of helicopter flight instrument panels. Applied ergonomics, 51, 85-101.

Altuntaş, S., Dereli, T., \& Özşalap, C. (2019). Kalite fonksiyonu göçerimi (KFG) ile askeri havacılıktaki bakım faaliyetleri için yeni ürün tasarımı. Gazi Üniversitesi Mühendislik Mimarlık Fakültesi Dergisi, 34(4), 2187-2202.

Behar, R. (2007). "Endüstri işletmelerinde çalışma koşullarının, işgörenler üzerindeki yabancılaşma etkisi ve bir uygulama”, Yüksek Lisans Tezi, Yıldız Teknik Üniversitesi, Sosyal Bilimler Enstitüsü, İstanbul.

Birrell, S. A., \& Haslam, R. A. (2010). The effect of load distribution within military load carriage systems on the kinetics of human gait. Applied ergonomics, 41(4), 585-590.

Bishop, P., Ray, P., \& Reneau, P. (1995). A review of the ergonomics of work in the US military chemical protective clothing. International Journal of Industrial Ergonomics, 15(4), 271-283.

Bolin, J., Crawford, C., Macke, W., Hoffman, J., Beckmann, S., \& Sen, S. (2017, May). Gesture-based control of autonomous UAVs. In Proceedings of the 16th Conference on Autonomous Agents and MultiAgent Systems (pp. 1484-1486).

Bozdemir, M. Silah Kabzasının 3b Yazıcılarla Tasarım Ve İmalatı. International Journal Of 3d Printing Technologies And Digital Industry, 2(1), 57-68. 
Carr, D.J., Wilson, C.A., Laing, R.M., 2012. Anthropometric methods for the successful design of military clothing and equipment. In: Advances in Military Textiles and Personal Equipment. Elsevier, pp. 49-63. https://doi.org/10.1533/9780857095572.1.49.

Coltman, C. E., Brisbine, B. R., Molloy, R. H., Ball, N. B., Spratford, W. A., \& Steele, J. R. (2021). Identifying problems that female soldiers experience with current-issue body armour. Applied Ergonomics, 94, 103384.

Czerwińska, M. (2014). “Zastosowanie nanomateriałów w przemyśle zbrojeniowym.” Chemik 6(68): 536-543.

Çelikkol, M. Askeri Havacılık Olay Ve Kazalarında İnsan Faktörünün Yorgunluk Yönüyle Değerlendirilmesi. Hv. Kk Lı̆̆g 2017 Havacılık Emniyeti Yönetim Sistemi (Heys 2017) Sempozyumu, 73.

Çiçek, H. \& Çağdaş, A. (2020). Ergonomik Faktörlerin Çalışan Performansına Olan Etkileri. Ohs Academy, 3 (2) , 135-143. Do1: 10.38213/Ohsacademy.733730

Dagge, R., \& Filgueiras, E. (2015). Military weight transportation systems: A biomechanical and design based approached review. Procedia Manufacturing, 3, 6075-6078.

Deringöz, A., Danışan, T., \& Tamer, E. (2021). Endüstriyel Giyilebilir Teknolojilerin Çkkv Yöntemleri İle Değerlendirilmesi Ve Seçimi. Ergonomi, 4(1), 10-21.

Doll, T. J., \& Folds, D. J. (1986). Auditory signals in military aircraft: ergonomics principles versus practice. Applied Ergonomics, 17(4), 257-264.

Duncan, S. , McLellan, T. and Gugdin Dickson, E. ( 2011 ). Improving comfort in military protective clothing. In: G. Song, ed. Improving comfort in clothing. Cambridge: Woodhead Publishing Limited, pp. 320 - 373.

Endrusick, T. L., Gonzalez, J. A., \& Gonzalez, R. R. (2005). Improved comfort of US military chemical and biological protective clothing. Environmental Ergonomics, 3, 369-373.

Endrusick, T. L., Cole, I. D., \& Matonich, P. M. (2005). Effects of simulated sustained operations on the thermal insulation of military footwear. Environmental Ergonomics, 3, 389-393.

Ersin, Ç., Mustafa, Y. A. Z., \& Karhan, M. (2019). Savunma Sanayi İçin Örnek Bir IoT Uygulaması. Electronic Letters on Science and Engineering, 15(3), 66-73.

Erol, A. D., \& Çetiner, S. (2017). Giyilebilir Elektronik/Akıllı Tekstiller ve Uygulamaları. Kahramanmaraş Sütçü İmam Üniversitesi Mühendislik Bilimleri Dergisi, 20(1), 1-20.

Gijsbertse, K., Linssen, L., Woering, A., \& Catoire, M. (2021). The effects of mass, bulk and stiffness of personal protective equipment and clothing on physical performance when performing a military mobility obstacle course. Applied Ergonomics, 95, 103448 .

Hamouda, A. M. S., Sohaimi, R. M., Zaidi, A. M. A., \& Abdullah, S. (2012). Materials and design issues for military helmets. In Advances in Military Textiles and Personal Equipment. Cambridge: Woodhead Publishing Limited, pp. 103-138.

Helvacılar, E., \& Eldem, C. (2017). İnsan Faktörleri Mühendisliği Bakış Açısı İle Askeri Mesaj İşletim Sistemleri. Gazi Mühendislik Bilimleri Dergisi (GMBD), 3(3), 41-46.

İstanbulluoğlu, H., \& Kır, T. (2016). Mesleki gürültü maruziyeti (Askeri personel örneği). TAF Preventive Medicine Bulletin, 15(4).

Karakoç, M., \& Ömer, A. S. A. L. (2017). Tsk Personelinin Kullanabileceği Giyilebilir Askeri Bilişim Sisteminin: Kullanılabilirliğini, Veri Tabanı Tasarımını Ve Kullanıcı Ara Yüzü Ekranlarını Belirlemeye Yönelik Anket Uygulaması. Türkiye Sosyal Araştırmalar Dergisi, 21(1), 261-278.

Kaya, N., \& Erden, O. (2019). Mayına Dirençli Askeri Personel Koltuğu Tasarımının Ekonomik Analizi, Mesleki Bilimler Dergisi (Mbd), Cilt.8, Sa.2, Ss.123-132, 2019.

Kılıç, D. (2019). Hücumbotların İç Mekân Tasarımı Ve Genel Yerleşim Planları İncelemesi (Yayımlanmamış Yüksek Lisans Tezi). Maltepe Üniversitesi, Fen Bilimleri Enstitüsü, İstanbul.

Kılıç, O. (2020). Askeri Denizaltıların İç Mekân Kurgularının Ergonomi Kapsamında İrdelenmesi. Elektronik Sosyal Bilimler Dergisi, 19(73), 383-394. 
Kieneke, R., Graf, C., \& Maas, J. (2013). Active seat suspension with two degrees of freedom for military vehicles. IFAC Proceedings Volumes, 46(5), 523-529.

Kolose, S., Stewart, T., Hume, P., \& Tomkinson, G. R. (2021). Prediction of military combat clothing size using decision trees and 3D body scan data. Applied Ergonomics, 95, 103435.

Krueger, G. P. (2012). Psychological issues in military uniform design. In Advances in military textiles and personal equipment (pp. 64-82e). Woodhead Publishing.

Labazanova, L., Tleugazy, A., Tsykunov, E., \& Tsetserukou, D. (2018, November). Swarmglove: A wearable tactile device for navigation of swarm of drones in vr environment. In International AsiaHaptics conference (pp. 304-309). Springer, Singapore.

Lee, W., Kim, H., Jung, D., Park, S., \& You, H. (2013, September). Ergonomic design and evaluation of a pilot oxygen mask. In Proceedings of the Human Factors and Ergonomics Society Annual Meeting (Vol. 57, No. 1, pp. 1673-1677). Sage CA: Los Angeles, CA: SAGE Publications.

Looney, D. P., Doughty, E. M., Figueiredo, P. S., Vangala, S. V., Pryor, J. L., Santee, W. R., ... \& Potter, A. W. (2021). Effects of modern military backpack loads on walking speed and cardiometabolic responses of US Army Soldiers. Applied Ergonomics, 94, 103395.

MacLeod, I. S. (2003). Real-world effectiveness of Ergonomic methods. Applied Ergonomics, 34(5), 465-477.

Maher, A., Li, C., Hu, H., \& Zhang, B. (2017, October). Realtime human-UAV interaction using deep learning. In Chinese Conference on Biometric Recognition (pp. 511-519). Springer, Cham.

McCaig, R. H., \& Gooderson, C. Y. (1986). Ergonomic and physiological aspects of military operations in a cold wet climate. Ergonomics, 29(7), 849-857.

McDaniel, J. W. (1996). The demise of military standards may affect ergonomics. International journal of industrial ergonomics, 18(5-6), 339-348.

Murray, M., Lange, B., Chreiteh, S. S., Olsen, H. B., Nørnberg, B. R., Boyle, E., ... \& Sjøgaard, G. (2016). Neck and shoulder muscle activity and posture among helicopter pilots and crew-members during military helicopter flight. Journal of Electromyography and Kinesiology, 27, 10-17.

Muslim, E., Moch, B. N., Rasyad, B. A. R. M., \& Risya, P. A. (2019, April). The Ergonomics Design Of The Military Backpack For Indonesian National Soldiers Using Virtual Environment Model. In IOP Conference Series: Materials Science And Engineering (Vol. 508, No. 1, P. 012108). IOP Publishing.

Müezzinoğlu, T., \& Karaköse, M. (2021). İnsan-İha Etkileşimi İçin Giyilebilir Eldiven Hareketlerinin Sınıflandırılması Ve Analizi. Fırat Üniversitesi Mühendislik Bilimleri Dergisi, 33(1), 141-150.

Nayak, R., Wang, L., \& Padhye, R. (2015). Electronic textiles for military personnel. In Electronic Textiles (pp. 239-256). Woodhead Publishing.

North, D. C. (1997). Where have we been and where are we going? , https://papers.ssrn.com/sol3/papers.cfm?abstract_id=1494, Son Erişim Tarihi: 10.10.2021.

Oord, M. V. D., Dresen, M. H. W. F., \& Sluiter, J. K. (2012). Optimal helmet use and adjustments with respect to neck load: The experience of military helicopter aircrew. International Journal of Industrial Ergonomics, 42(1).

Öter, E., Demir, A. A., \& Coşkun, Ö. Mikrodenetleyici Temelli Parmak Ucundan Nabız Ölçer Devresi Tasarımı. Mühendislik Bilimleri Ve Tasarım Dergisi, 4(2), 87-92.

Özer, Y., (2019). Nanoteknoloji’nin Askerî Uygulamaları Üzerine Bir Değerlendirme. Güvenlik Bilimleri Dergisi, $33-52$.

Park, D. J., Choi, M. G., Song, J. T., Ahn, S. J., \& Jeong, W. B. (2019). Attention decrease of drivers exposed to vibration from military vehicles when driving in terrain conditions. International Journal of Industrial Ergonomics, 72, $363-371$.

Penrice, C. (2000). Single seat fighter-the way ahead for the 21st century. Air \& Space Europe, 2(1), 8-14.

Silah, M. (2005). İşletmelerde Personel Seçme ve İşe Yerleştirmede Psikoteknik Bir Uygulama Örneği: Giyim Sanayi Konfeksiyon Atölyelerinde Çalışacakların Seçiminde From Lege Testi Uygulaması. Cumhuriyet Üniversitesi, Iktisadi ve İdari Bilimler Dergisi, $6(1), 177-192$. 
Strain, J. D., \& Preece, D. A. (1999). Project management and the integration of human factors in military system procurement. International Journal of Project Management, 17(5), 283-292.

Tharion, W. J., \& Obusek, J. P. (2000). Effects of a new individual fighting system on marksmanship. International journal of industrial ergonomics, 25(1), 79-84.

Tseng, F. Y., Chao, C. J., Yau, Y. J., \& Feng, W. Y. (2018). Design and evaluation of military geographical intelligence system: An ergonomics case study. Displays, 51, 36-42.

Tsykunov, E., Agishev, R., Ibrahimov, R., Labazanova, L., Moriyama, T., Kajimoto, H., \& Tsetserukou, D. (2019). SwarmCloak: Landing of a Swarm of Nano-Quadrotors on Human Arms, https://dl.acm.org/doi/abs/10.1145/3355049.3360542, Son Erişim Tarihi: 10.10.2021.

Tutton, W., \& Denton, H. (2012). Designing load carriage systems for military personnel. In Advances in Military Textiles and Personal Equipment. Cambridge: Woodhead Publishing Limited, pp. 288 - 305.

Van den Oord, M. H., Frings-Dresen, M. H., \& Sluiter, J. K. (2012). Optimal helmet use and adjustments with respect to neck load: The experience of military helicopter aircrew. International Journal of Industrial Ergonomics, 42(1), 73-79.

Walsh, G. S., \& Low, D. C. (2021). Military load carriage effects on the gait of military personnel: A systematic review. Applied ergonomics, 93, 103376.

Williams, D. H., \& Simpson, C. A. (1976). A systematic approach to advanced cockpit warning systems for air transport operations: Line pilot preferences. https://ui.adsabs.harvard.edu/abs/1976NASSP.416..617W/abstract, Son Erişim Tarihi: 10.10.2021.

Wu, F., Ramchurn, S. D., \& Chen, X. (2016). Coordinating human-UAV teams in disaster response. In Proceedings of the 25th International Joint Conference on Artificial Intelligence (IJCAI) (pp. 524-530).

Zerehsaz, Y., Jin, J. J., Ebert, S. M., \& Reed, M. P. (2017). Statistical prediction of eye locations for drivers of military ground vehicles. International Journal of Industrial Ergonomics, 59, 20-28. 